\title{
STUDI EKSPERIMENTAL DAN PEMODELAN MATEMATIKA PROSES PENGERINGAN KAKAO DENGAN ENERGI SURYA SECARA INTERMITTEN
}

\section{Experimental Study and Mathematical Modeling of Cocoa Drying Process with Solar Energy Intermittenly}

\author{
Haznam Putra ${ }^{* 1}$, Farrel H Napitupulu', Himsar Ambarita', Sari Farah Dina ${ }^{2}$ \\ 1 Teknik Mesin - Fakultas Teknik, Universitas Sumatera Utara, \\ JI. Almamater, Kampus USU Medan - 20155 \\ 2 Balai Riset dan Standardisasi Industri Medan, Jl. Sisingamangaraja No. 24 Medan - 20217 \\ *Email: haznam.putra@gmail.com
}

Diterima: 27 Januari 2014, revisi akhir: 12 Mei 2014 dan disetujui untuk diterbitkan: 23 Mei 2014

\begin{abstract}
ABSTRAK
Pada penelitian ini, perilaku pengeringan menggunakan pengering kakao tenaga surya telah dilakukan. Kakao diambil dari perkebunan di sekitar daerah Sumatera Utara - Indonesia. Energi surya digunakan sebagai sumber energi pengeringan yang hemat dan bersih. Kakao merupakan komoditi andalan di Indonesia hanya saja mutu yang saat ini dihasilkan masih terbilang rendah. Penelitian ini bertujuan untuk mendapatkan persamaan pengeringan dengan pemodelan matematika untuk menghasilkan mutu kakao yang baik. Tahap preparasi dimulai dari proses fermentasi kakao. Dari beberapa kali pengujian kakao, diambil hasil salah satu pengujian dimana hasil fermentasi kakao yang telah dicuci kemudian dikeringkan dari kadar air $55,83 \%$ menjadi $7,01 \%$ yang berlangsung selama tiga hari secara intermitten. Penelitian dilakukan di Laboratorium Solar Energi Jurusan Teknik Mesin Fakultas Teknik Universitas Sumatera Utara kota Medan dengan posisi $3.36^{\circ} \mathrm{LU}-98.4^{\circ} \mathrm{BT}$, ketinggian di atas permukaan laut 200 meter dan waktu meridian (7+GMT). Dari hasil percobaan didapat persamaan model matematika untuk pengeringan kakao secara intermitten, dengan nilai koefisien difusifitas berada pada nilai $1,39 \times 10^{-10}-1,85 \times 10^{-10} \mathrm{~m}^{2} /$ detik, selain itu kualitas kakao yang dikeringkan lebih baik dari segi warna dan tidak berjamur dibandingkan dengan kakao yang dikeringkan secara langsung di bawah sinar matahari.
\end{abstract}

\section{Kata Kunci : Pengeringan kakao, energi surya, koefisien diffusivitas, intermittent}

\section{ABSTRACT}

In this research had been studied behaviors of cocoa drying using solar energy. Cocoa was taken from plantation area around North Sumatra - Indonesia. Solar energy is used as a source of energy that save and clean for drying. Cocoa is a mainstay in Indonesian commodities, but quality of the current generated is relatively low. The aims of this research to gain the quality with mathematical model of drying to produce a good quality of cocoa. Preparation phase was started from cocoa fermentation process. With some testing, it was taken one test where the results of fermented cocoa that had been washed and dried from water content $55.83 \%$ became $7.01 \%$, which lasted for three days intermittently. The study was conducted at the Solar Energy Laboratory, Faculty of Engineering Department of Mechanical Engineering of North Sumatra University Medan. It is located in Medan city with the position of $3.36^{\circ} \mathrm{N}-98.4^{\circ} \mathrm{E}$, altitude 200 meters above sea level and meridian time $(G M T+7)$. From the experimental results obtained an equation of mathematical model for drying of cocoa intermittenly, with the value of diffusivity coefficient was between $1.39 \times 10^{-10}$ to $1.85 \times 10^{-10} \mathrm{~m}^{2} / \mathrm{sec}$, besides the quality of the dried cocoa in this study was better in colour and not moldy than dried cacao directly under the sun.

Keywords: Cocoa drying, solar energy, diffusivity coefficient, intermittent 


\section{PENDAHULUAN}

Kebijakan energi yang berkelanjutan (sustainable energy) telah mempengaruhi banyak sektor yang berhubungan dengan penggunaan energi. Pilar utamanya ada dua, yaitu: pertama bagaimana menggunakan energi secara efisien dan kedua meningkatkan penggunaan sumber-sumber energi baru dan terbarukan untuk mengurangi atau menggantikan penggunaan energi yang berasal dari fosil. Salah satu sektor yang banyak mengkonsumsi energi adalah pengeringan produk, baik hasil pertanian, makanan, dan juga hasil industri seperti kertas. Studi di beberapa negara menunjukkan bahwa persentasi konsumsi energi nasional untuk pengeringan relatif cukup besar. Menurut studi, negara-negara seperti USA, Kanada, Perancis dan Inggris mengkonsumsi sekitar $10-15 \%$ dari energi nasionalnya untuk pengeringan. Jerman dan Denmark bahkan lebih besar yaitu sekitar $20-25 \%$. Meskipun belum ada studi yang melaporkannya, diperkirakan Indonesia dan negara-negara lainnya, menggunakan konsumsi energi nasionalnya untuk pengeringan pada kisaran 5-25\%. Oleh karena alasan ini, maka sangat diperlukan usaha penggunaan energi pada proses pengeringan secara efisien.

Pengeringan adalah proses perpindahan massa dan perpindahan panas secara simultan. Analisis dari proses ini sangatlah kompleks, terutama karena sifatnya yang transien. Salah satu permasalahan dalam pengeringan yang masih tetap mendapat perhatian dari para peneliti adalah merumuskan model pengeringan (drying kinetics). Model pengeringan yang akurat (rigorous) sangat diperlukan untuk mendukung usaha-usaha pengembangan inovasi pada proses pengeringan dan menghasilkan teknik pengeringan yang lebih efisien (Jangam, 2010). Misalnya, untuk mengetahui pengaruh humiditas dan pengaruh perlakuan intermitten dari udara pengering.

Kakao (Theobroma cacao) telah menjadi komoditi penting di pasaran dunia. Dijumpai dua jenis kakao yang umum dipasaran yakni biji yang tidak difermentasi dan yang difermentasi. Kakao merupakan tanaman tahunan yang menjadi salah satu unggulan ekspor non migas di Indonesia. Menurut data dari FAO, produksi kakao Indonesia di tahun 2010 adalah 680.000 Ton atau nomor dua setelah Pantai Gading 1.610.000 Ton (Anonim, 2009). Namun ditinjau dari sisi kualitas, biji kakao yang diekspor oleh Indonesia dikenal memiliki mutu rendah dan sebagian besar merupakan jenis tidak difermentasi.

Dua proses penting yang diperlukan dalam membangun kualitas kakao adalah tahap fermentasi dan pengeringan. Fermentasi biji kakao akan menghasilkan prekursor cita rasa, mencokelat-hitamkan warna biji (Gambar 1), mengurangi rasa pahit, asam, manis dan aroma bunga, meningkatkan aroma kakao dan kacang (nutty), (Sharma et al, 2009), serta mengeraskan kulit biji menjadi seperti tempurung. Biji yang tidak difermentasi tidak akan memiliki senyawa prekursor tersebut sehingga cita rasa dan mutu biji sangat rendah (Anonim ${ }^{a}$, 2009).

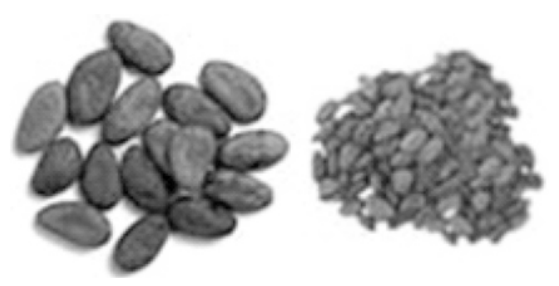

Gambar 1. Biji kakao kering terfermentasi dengan kadar air $6-7,5 \%$

Selanjutnya biji kakao baik yang difermentasi maupun tidak, harus dikeringkan. Pengeringan dilakukan sampai kadar air menjadi $6-7,5 \%$. Kadar air kurang dari $6 \%$, biji akan rapuh sehingga penanganan dan pengolahan lanjutan menjadi lebih sulit. Kadar air lebih dari 9\% memungkinkan pelapukan biji oleh jamur (Dina dkk, 2013). Pengendalian laju pengeringan yang tepat akan menghasilkan biji kakao dengan kadar air $6-7,5 \%$ dan dapat menurunkan kadar keasaman biji serta rasa pahit dan penciutan berlebih (Fagunwa dkk, 2009).

Pada proses pengeringan kakao, petani kakao biasanya akan menjemur biji kakao langsung di bawah sinar matahari (open sun). Cara ini tentu kurang efektif karena sangat bergantung pada kondisi cuaca dan perlu lahan yang cukup luas bila produk yang dikeringkan dengan kapasitas besar. 
Pemodelan matematika (empirik) dibangun dengan menggunakan data hasil proses pengeringan sebagai fungsi waktu. Dasar dari pengembangan model ini adalah penyelesaian eksak dari persamaan transien seragam (lumped system analysis). Asumsi utama yang digunakan di sini adalah temperatur dan konsentrasi air di dalam produk adalah merata/seragam dan hanya merupakan fungsi waktu. Sebagai akibatnya laju penurunan kandungan air di dalam produk adalah kasus 1 dimensi, dan penyelesaiannya, dinyatakan dengan bilangan tanpa dimensi perbandingan rasio (Moisture Ratio, MR).

Mengingat wilayah Indonesia yang dilalui garis khatulistiwa, sinar matahari cukup melimpah di negara kita sehingga pengembangan teknologi tepat guna yang memanfaatkan sinar matahari sebagai energi alternatif sangat diperlukan. Aplikasinya dalam bidang pengering berupa mesin pengering tenaga surya yang memanfaatkan sinar matahari untuk memanaskan udara pengering yang akan diumpankan pada produk.

Tujuan dari tulisan ini adalah untuk mengetahui pengaruh karakteristik udara, radiasi matahari, temperatur dan humiditas relatif pada perilaku proses pengeringan kakao menggunakan energi surya secara tidak langsung melalui metode pemodelan matematika. Hasil yang diharapkan dari penelitian awal ini adalah mendapatkan metode yang akurat dalam memodelkan proses pengeringan kakao serta meningkatkan kualitas kakao hasil pengeringan.

\section{METODOLODI PENELITIAN}

Percobaan pengeringan dengan menggunakan alat pengering energi surya dilakukan selama periode Maret-Agustus 2013. Penelitian dilakukan di Laboratorium Energi Surya Teknik Mesin USU posisi $3.36^{\circ}$ $\mathrm{LU}-98.4^{\circ} \mathrm{BT}$, ketinggian di atas permukaan laut 200 meter dan waktu meridian $(7+$ GMT). Percobaan dimulai pada pukul 07.00 WIB di pagi hari hingga 17.00 WIB di sore hari. Sifat intermitten masih terjadi pada pengujian ini.

Selama percobaan, radiasi harian matahari berubah antara $23,1-884,4 \mathrm{~W} / \mathrm{m}^{2}$. Temperatur udara pengeringan berkisar $25,1-53,31^{\circ} \mathrm{C}$, dan humiditas relatif udara pengeringan berkisar $34-89,5 \%$. Energi radiasi maksimum terjadi pada tengah hari dan minimum pada pagi dan sore hari.

Percobaan pengeringan dilakukan mengunakan alat pengering energi surya dengan dimensi seperti Gambar 1.

$$
\begin{array}{ll}
\text { Kolektor } & :(10 \times 50 \times 200) \mathrm{cm} \\
\text { Box Pengering } & :(50 \times 50 \times 100) \mathrm{cm} \\
\text { Rak Pengering } & :(40 \times 40) \mathrm{cm}
\end{array}
$$

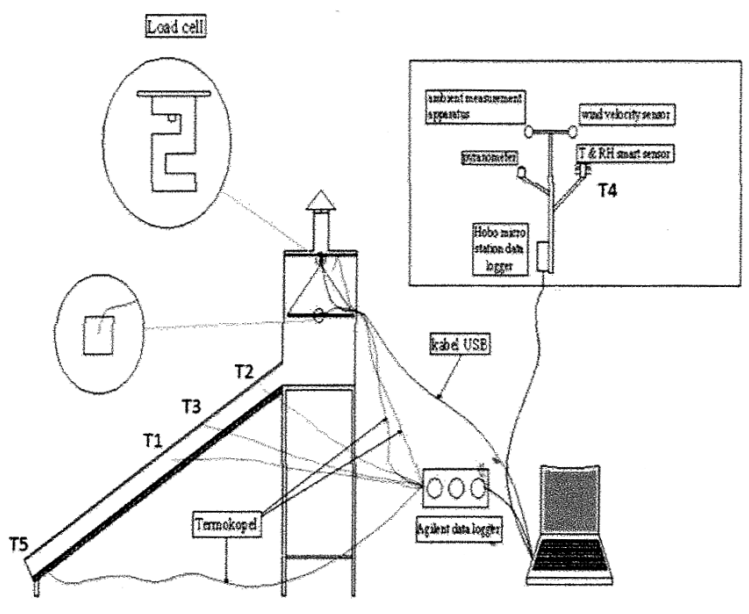

Gambar2. Mesin pengering kakao energi surya

Alat pengering energi surya ini dibuat berdasarkan hasil rancangan terlebih dahulu guna mendapatkan rata-rata temperatur pengeringan $45-55^{\circ} \mathrm{C}$. Alat pengering dibuat bertujuan untuk mempercepat pengeringan produk pertanian.

Pada alat pengering energi surya tersebut dilengkapi dengan sensor temperatur, humiditas relatif dan massa yang dapat dihubungkan ke komputer sehingga data-data pengeringan dapat terekam secara real time per 5 menit. Untuk parameter lingkungan digunakan Hobo Micro station Data Logger yang terdiri dari pyranometer, wind velocity sensor, ambient aparatus sensor dan $\mathrm{T} \& \mathrm{RH}$ smart sensor yang mampu merekam nilai radiasi matahari, humiditas relatif, temperatur, dan kecepatan angin.

Sebanyak $1 \mathrm{~kg}$ biji kakao terfermentasi yang didapat diletakkan di atas rak pengering secara thin layer. Kadar air awal didapat $55,83 \%$ dikeringkan selama 3 hari secara intermittent hingga tidak ada perubahan massa dan didapat kadar air akhir $7,01 \%$. 


\section{HASIL DAN PEMBAHASAN Kondisi Lingkungan}

Hasil pengukuran radiasi, temperatur dan humiditas relatif lingkungan selama 3 hari (22-24 April 2013) tersebut disajikan pada (Gambar 3).
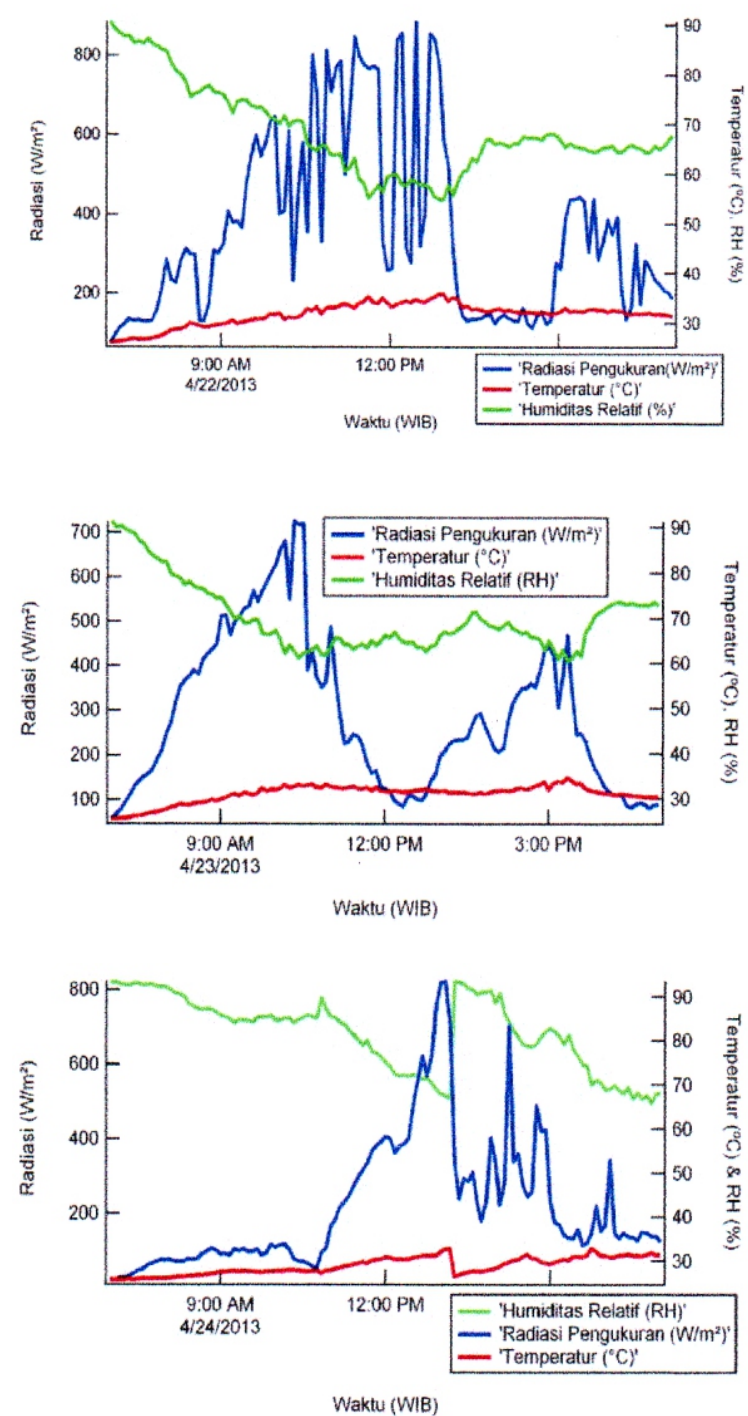

Gambar 3. Radiasi, temperatur \& humiditas relatif lingkungan 22-24 April 2013

Pengujian 22-24April 2013

Radiasi Pengukuran

$\begin{array}{ll}\text { Range } & =23,1-884,4 \mathrm{~W} / \mathrm{m}^{2} \\ \text { Rata-Rata } & =289.68 \mathrm{~W} / \mathrm{m}^{2}\end{array}$
Temperatur Lingkungan

$$
\begin{array}{ll}
\text { Range } & =25,38-35,823^{\circ} \mathrm{C} \\
\text { Rata-Rata } & =30,51^{\circ} \mathrm{C}
\end{array}
$$

Humiditas Relatif Lingkungan
Range
$=55-93,5 \%$
Rata-Rata

$$
=73,36 \%
$$

Dari Gambar 3 dapat dilihat nilai temperatur lingkungan berbanding lurus dengan nilai radiasi pengukuran. Hal sebaliknya terjadi pada nilai humiditas relatif $(\mathrm{RH})$ yang berbanding terbalik dengan nilai radiasi pengukuran.

\section{Kondisi Pengeringan}

Prinsip kerja kolektor plat datar ini adalah mengubah energi radiasi matahari yang jatuh pada permukaan absorber kolektor menjadi energi termal yang selanjutnya dipindahkan ke udara yang mengalir di atas permukaan kolektor. Energi panas yang diserap oleh udara kemudian dimanfaatkan untuk pengeringan biji kakao.

Pengujian 22-24April 2013

Temperatur Box Pengering

$\begin{array}{ll}\text { Range } & =25,38-53,31^{\circ} \mathrm{C} \\ \text { Rata-Rata } & =36,79^{\circ} \mathrm{C}\end{array}$

Temperatur Inti Kakao

Range $=24,41-45,15^{\circ} \mathrm{C}$

Rata-Rata $=32,12^{\circ} \mathrm{C}$

Diasumsikan distribusi temperatur baik pada ruang pengering dan di dalam inti buah adalah seragam. Dapat dilihat pada Gambar 4.

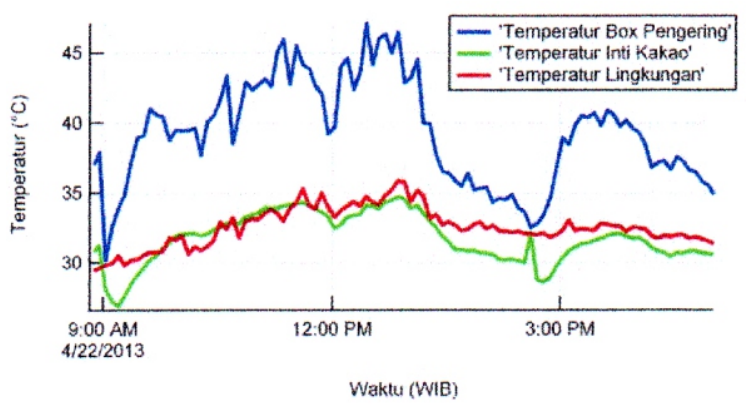



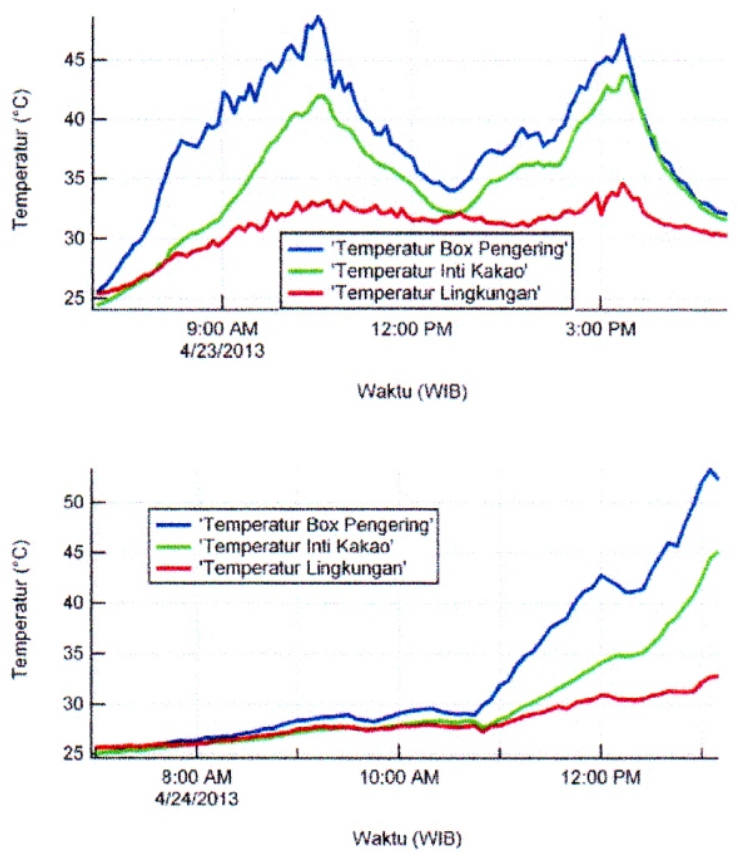

Gambar 4. Temperatur box pengering, temperatur inti kakao dan temperatur lingkungan pada pengujian tanggal 22-24 April 2013.

Nilai humiditas relatif udara pengering merupakan salah satu faktor cepat atau lambatnya laju pengeringan biji kakao yang terjadi.

Pengujian 22 - 24 April 2013

Humiditas Relatif Box Pengering (In)

$\begin{array}{ll}\text { Range } & =34-89,5 \% \\ \text { Rata-Rata } & =59,42 \%\end{array}$

Humiditas Relatif Box Pengering (Out)

Range $=28,5-90 \%$

Rata-Rata $=53,59 \%$

Kenaikkan temperatur box pengering mengakibatkan kadar air didalam udara berkurang dapat dilihat pada Gambar 5 .

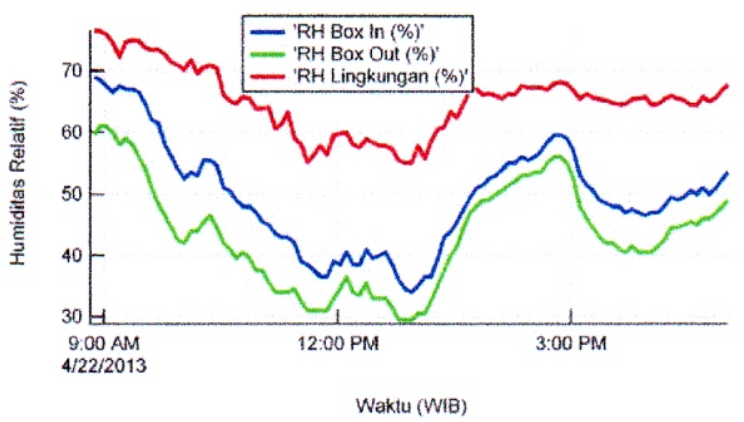

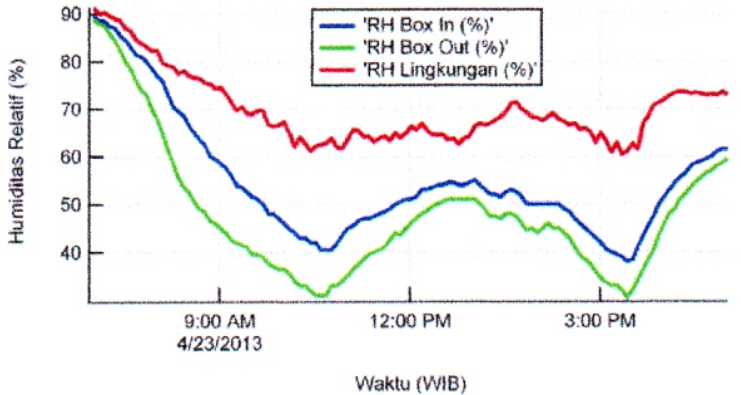

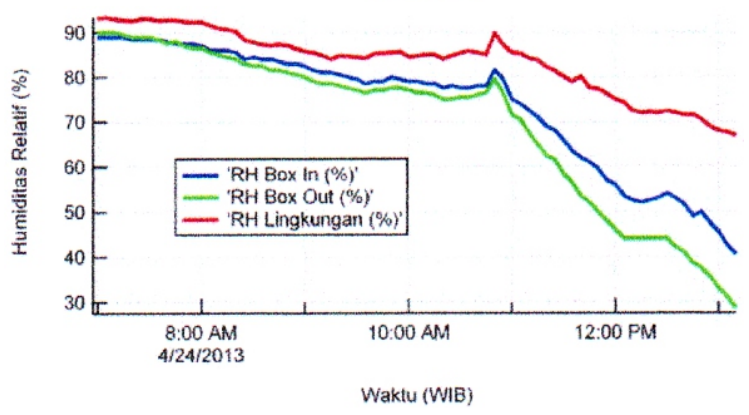

Gambar 5. Humiditas relatif box pengering \& humiditas relatif lingkungan pengujian tanggal 22-24 April 2013.

\section{Kinetika Pengeringan}

Biji kakao, dianggap sebagai satu lapisan dikeringkan di dalam box pengering energi surya dari massa awal $1.002 \mathrm{~g}$ menjadi $476 \mathrm{~g}$ dimana tidak ada penurunan lebih lanjut dari massa kakao yang dikeringkan.

Karakteristik pengeringan kakao dapat ditampilkan dalam bentuk kurva penurunan moisture ratio (MR) kakao terhadap waktu pengeringan (persamaan 1). Rasio kadar air (MR) digunakan sebagai variabel fungsi yang berkaitan dengan kadar air awal $\left(M_{i}\right)$, kadar air setimbang $\left(\mathrm{M}_{\mathrm{e}}\right)$ dan kadar air pada waktu aktual $\left(\mathrm{M}_{\mathrm{t}}\right)$.

$$
M R=\left(M_{t}-M_{e}\right) /\left(M_{t}-M_{e}\right)
$$

Namun untuk pengeringan yang memerlukan waktu panjang maka nilai MR disederhanakan menjadi MR $=M_{\mathrm{t}} / \mathrm{M}_{\mathrm{i}}$ karena nilai $M_{e}$ relatif kecil dibanding $M_{t}$ atau $M_{i}$ (Clement, 2009). Pada umumnya studi pengeringan menggunakan penyelesaian analitik melalui model persamaan diffusi dari Hukum Fick's kedua, satu dimensi untuk geometri bola yang telah didiskritisasi sesuai dengan interval jari-jari $(r)$ dan waktu $(t)$, (persamaan 2). 


$$
\frac{\partial X}{\partial t}=D_{\text {eff }} \frac{\partial^{2} X}{\partial^{2} t}+\frac{2}{r} \frac{X}{r}
$$

Dimana :

X adalah kadar air ( $\mathrm{kg}$ air/kg bahan kering)

$D_{\text {eff }} \quad$ diffusivitas efektif $\left(\mathrm{m}^{2} / \mathrm{det}\right)$

$r \quad$ jari-jari ekivalen bola, $m$

t waktu, detik

Moisture ratio terhadap waktu ditampilkan pada Gambar 6. Diamati bahwa moisture ratio berkurang secara kontinu terhadap waktu dan tidak ada periode laju pengeringan konstan. Model kinetika yang digunakan adalah model persamaan empirik yang dibangun menggunakan data hasil percobaan berupa laju penurunan berat sebagai fungsi waktu.

Hasil percobaan (Gambar 7) jika dibandingkan dengan hasil percobaan Hii, dkk $\left(2009^{\mathrm{a}}\right)$ (Gambar 8) menunjukkan model yang kurva yang sama, meskipun waktu pengeringannya berbeda. Asumsi utama yang digunakan di sini adalah temperatur dan konsentrasi air di dalam produk adalah merata/seragam dan hanya merupakan fungsi waktu. Sebagai akibatnya laju penurunan kandungan air di dalam produk adalah kasus 1 dimensi, dan penyelesaiannya, dinyatakan dengan bilangan tanpa dimensi perbandingan rasio (Moisture Ratio, MR). Model sederhana ini lebih dikenal dengan model pengeringan Newton. Dari hasil pencocokan kurva dapat dibuktikan bahwa jika kadar air kakao masih berada pada kisaran kadar air $>10 \%$ atau MR > 0,1 maka proses penguapan berlangsung secara eksponensial dan setelah $\mathrm{MR}<0,1$ pola penurunan kadar air berubah menjadi polynomial. Koefisien $\left(R^{2}\right)$ tertinggi adalah kriteria utama untuk memilih model terbaik untuk menggambarkan kurva pengeringan.

Keterangan persamaan model empirik pada pengujian 22-24 April 2013 sebagai berikut :

\section{April 2013:}

$$
\begin{aligned}
& M R=e^{-3 \times 10^{-5} \dot{C}} \\
& \mathrm{R}^{2}=0,973
\end{aligned}
$$

23April 2013:

$$
M R=0,7551 e^{-3 \times 10^{-5} \dot{C}}
$$

$\mathrm{R}^{2}=0,9904$
24April 2013:

$M R=-3 \times 10^{-10} t^{2}+4 \times 10^{-5} t-1,1467$

$\mathrm{R}^{2}=0,966$
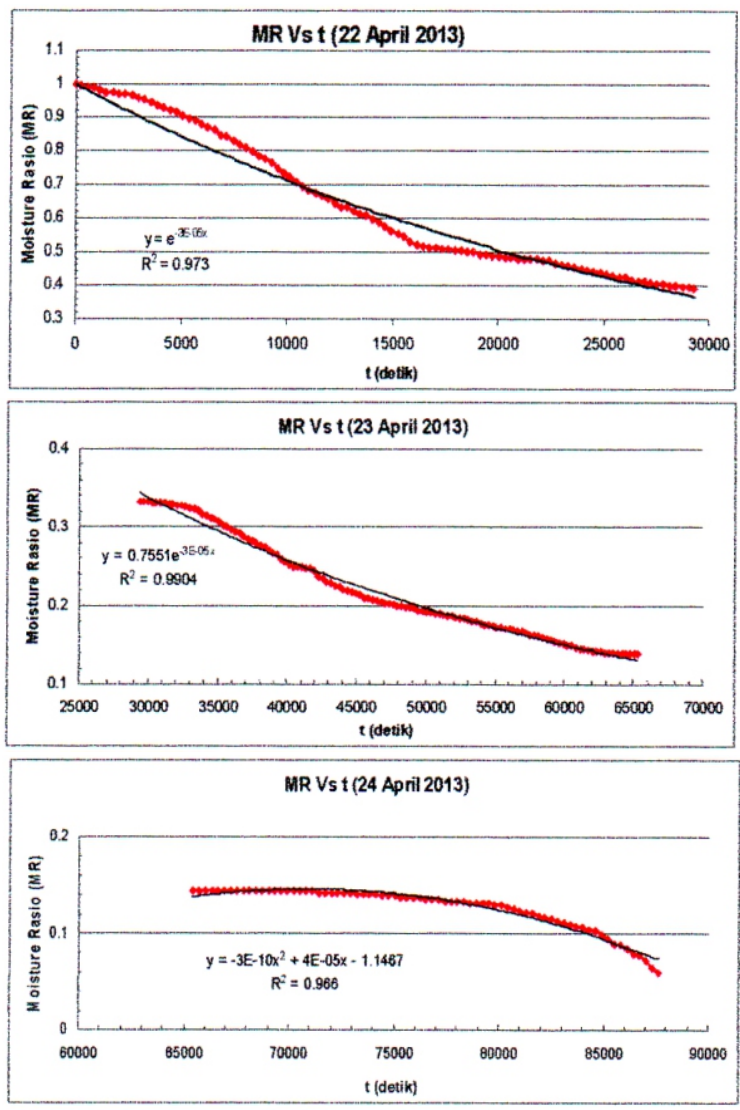

Gambar 6. Moisture ratio vs waktu pengujian tanggal 22-24 April 2013

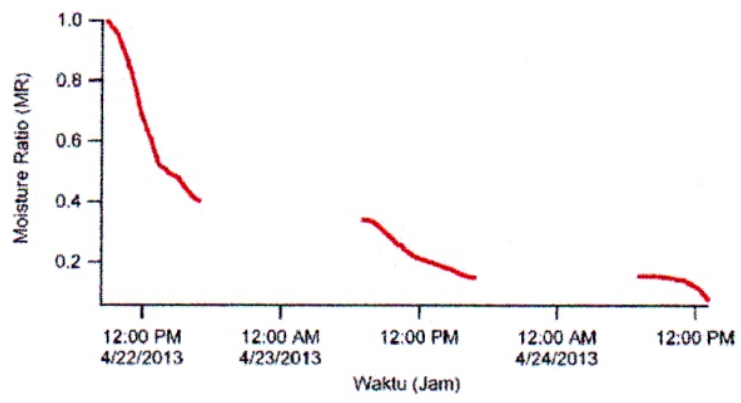

Gambar 7. Moisture ratio vs waktu hasil penelitian

Selain $R^{2}$ parameter statistik seperti root mean square error (RSME) dihitung untuk mengevaluasi pencocokan model dengan data eksperimen. RSME dihitung menggunakan persamaan 3 .

$$
\left.R S M E=\frac{1}{N} \sum_{i-1}^{N}\left(M R E_{\text {exp }, i}-M R E_{p r e d, i}\right)^{2}\right]^{1 / 2}
$$




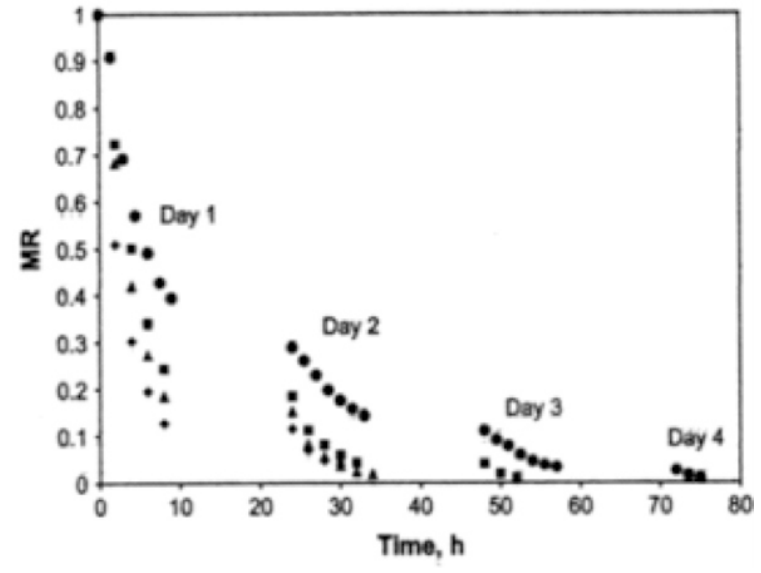

Gambar 8. Moisture ratio vs waktu hasil penelitian asing (Hii dkk, 2009 $)$.

Dari hasil tingkat kesalahan akar ratarata (root mean square error RMSE)

Hari ke 1: 22 April 2013, RSME $=0,05$

Hari ke $2:$ 23 April 2013, RSME $=0,03$

Hari ke 3 : 24 April 2013, RSME =0,04

Dari model persamaan eksponensial ini menunjukkan bahwa pada awal pengeringan (hari pertama) laju pengeringan adalah paling tinggi. Penurunan kadar air yang lebih tinggi selama tahap awal pengeringan dikarenakan evaporasi kandungan uap air bebas dari lapisan permukaan lebih luar. Laju pengeringan menurun (berjalan lambat) ketika kandungan uap air dipermukaan biji berkurang sehingga terjadi migrasi kadar air internal dari lapisan dalam ke permukaan biji.

\section{Diffusivitas Efektif $\left(D_{\text {eff }}\right)$}

Diffusivitas efektif adalah suatu sifat perpindahan massa air secara keseluruhan pada pengeringan bahan, didalamnya termasuk diffusi larutan, diffusi uap, aliran hidrodinamik dan kemungkinan mekanisme perpindahan massa lainnya (Karathanos, 1999). Penyelesaian umum untuk diffusi keadaan tidak konstan satu-dimensi menggunakan beberapa asumsi yang wajar, maka penyelesaian analitik dapat diturunkan terhadap beberapa bentuk geometri yang standar seperti lempeng, silinder dan bola. Persamaan (1) dan (2) diselesaikan untuk pengeringan biji kakao dengan asumsi bahwa objek adalah berbentuk bola (Hii dkk, $\left.2009^{b}\right)$.

$$
M R=\frac{6}{\pi^{2}} \sum_{n=1}^{\infty} \frac{1}{n^{2}} \exp \frac{D_{\text {eff }} \cdot n^{2} \cdot \pi^{2} \cdot t}{r^{s}}
$$

Pada pengeringan yang berlangsung lama, maka ditetapkan $\mathrm{n}=1$ dan persamaan (4) dapat dilinierkan (Doymaz, 2005) sebagai berikut:

$$
\operatorname{Ln} M R=\operatorname{Ln}\left(\frac{6}{\pi^{2}}\right)-\left(\frac{\pi^{2}, D_{\text {eff }} \cdot t}{r^{2}}\right)
$$

Diffusivitas efektif diperoleh dengan memplot data Ln MR dan t (detik) dengan slope $\mathrm{K}_{1}($ Doymaz, 2005) sebagai berikut :

$$
\mathrm{K}_{1}=\frac{\pi^{2} \cdot \mathrm{D}_{\text {eff }}}{\mathrm{r}^{9}}
$$

Pengaruh suhu terhadap konstanta diffusivitas $\left(D_{0}\right)$ dan energi aktivasi (Ea) umumnya dinyatakan menggunakan persamaan Arrhenius seperti ditunjukkan oleh persamaan berikut (Hii dkk, $\left.2009^{\circ}\right)$ :

$$
D_{\text {eff }}=D_{0} \exp \left(-\frac{E_{a}}{R T}\right)
$$

Karena adanya masa tempering pada malam hari, maka pemodelan dilakukan hanya selama masa pengeringan siang hari saja. Pemodelan diselesaikan dengan bantuan program Microsoft Excel Spreadsheet (Microsoft Office 2007, USA).

$D_{\text {eff }}$ dari semua hasil percobaan berkisar antara $1,39.10^{-10}-1,85.10^{-10}$ hasil ini masih berada dalam range hasil penelitian (Hii, dkk, 2009 ${ }^{\mathrm{a}}$ ) menggunakan oven $60-80{ }^{\circ} \mathrm{C}$ menghasilkan nilai $D_{\text {eff }}$ antara $7,46.10^{-11}$ $1,87.10^{-10}$. Salah satu variabel yang mempengaruhi nilai $D_{\text {eff }}$ adalah temperatur pengeringan. Semakin tinggi temperatur maka semakin tinggi $D_{\text {eff, }}$, selain itu aktivitas air juga mempengaruhi. Pada hari pertama laju penurunan konsentrasi air bergerak secara eksponensial dan berbanding lurus dengan nilai $D_{\text {eff. }}$. Pada hari kedua dan ketiga nilai $D_{\text {eff }}$ semakin menurun. 
Nilai diffusivitas efektif dari pengeringan kakao sistem intermitten (berselang) yakni berlangsung hanya pada siang hari pengeringan dibagi dalam tiga hari seperti pada Tabel 1 .

Tabel 1. Nilai Diffusifitas Effektif pengujian 22-24 April 2013

\begin{tabular}{|c|c|c|c|}
\hline $\begin{array}{c}\text { Solar } \\
\text { Drying }\end{array}$ & $\begin{array}{c}\text { Hari 1 } \\
\left(\mathrm{m}^{2} / \mathrm{sec}\right)\end{array}$ & $\begin{array}{c}\text { Hari 2 } \\
\left(\mathrm{m}^{2} / \mathrm{sec}\right)\end{array}$ & $\begin{array}{c}\text { Hari 3 } \\
\left(\mathrm{m}^{2} / \mathrm{sec}\right)\end{array}$ \\
\hline $\begin{array}{c}\text { Pengujian } \\
(22-24 \\
\text { April } \\
2013)\end{array}$ & $1,85.10^{-10}$ & $1,39.10^{-10}$ & $1,39.10^{-10}$ \\
\hline
\end{tabular}

\section{Mutu Kakao}

Pengeringan buatan berbasis energi surya (solar drying) memiliki beberapa keunggulan dibandingkan pengeringan matahari langsung (open sun drying) diantaranya mengurangi resiko pembusukan dan meningkatkan kualitas produk. Pada pengeringan berbasis energi surya, biji kakao tidak langsung dikenai radiasi matahari. Hal ini untuk meminimalisasi perusakan warna dan peretakan pada permukaan biji. Selain itu pada pengeringan matahari langsung dimana terjadi temperatur pengeringan yang terlalu tinggi (menyebabkan pengeringan dini) sehingga menyebabkan case hardening sehingga asam-asam volatil tidak dapat keluar melewati kulit biji yang mengeras. Asam volatil yang tinggi dapat mengurangi kualitas produk kakao yang dihasilkan. Perbandingan hasil produk kakao yang dikeringkan menggunakan metode solar drying dan metode open sun drying dapat dilihat pada Gambar 9 dan 10.

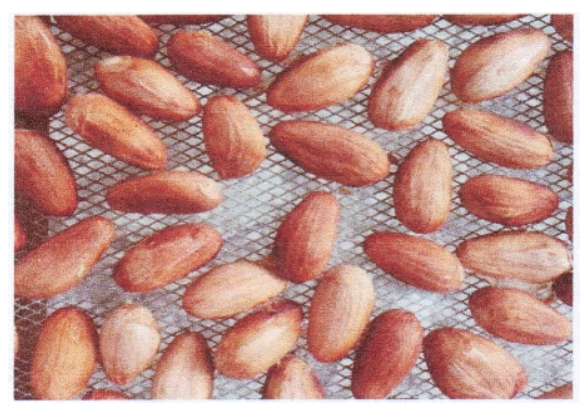

Gambar 9. Produk Kakao hasil pengeringan menggunakan metode solar drying (warna lebih cerah dan tidak berjamur)

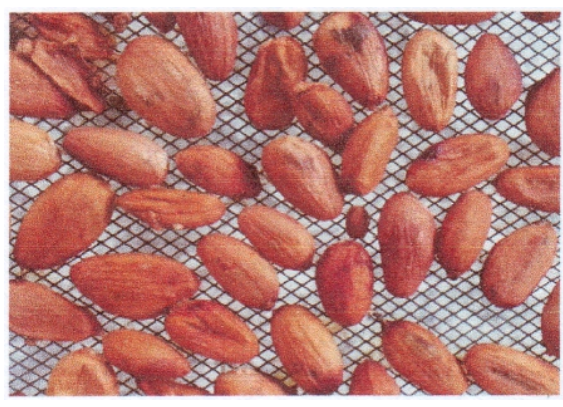

Gambar 10. P r o d u k Kaka o has il pengeringan menggunakan metode open sun drying (warna lebih gelap dan sedikit berjamur)

\section{KESIMPULAN DAN SARAN}

\section{Kesimpulan}

Atas dasar penelitian yang dilakukan tentang pengeringan kakao secara intermitten (22-24 April 2013, pukul 07.0017.00 WIB) menggunakan metoda solar thermal dengan intensitas matahari 23,1$884,4 \mathrm{~W} / \mathrm{m}^{2}$ (hasil pengukuran HOBO) didapatkan bahwa semakin tinggi temperatur pengeringan, maka semakin besar laju penguapan air. Namun kondisi intermitten dapat menyebabkan reabsorpsi uap air ke biji kakao akibat adanya perbedaan tekanan uap antara biji kakao dengan udara.

Hasil pencocokan kurva menunjukkan bahwa jika MR $>0,1$ maka model kinetika pengeringan untuk semua metoda adalah eksponensial namun ketika MR $<0,1$ maka kurva cenderung membentuk polinomial. Diffusivitas effektiff $\left(D_{\text {eff }}\right)$ dipengaruhi oleh temperatur pengeringan, semakin tinggi temperatur maka nilai $D_{\text {eff }}$ semakin tinggi. Dari semua hasil percobaan berkisar antara $1,39.10^{-10}-1,85.10^{-10} \mathrm{~m}^{2} /$ detik.

Mutu kakao hasil pengeringan energi surya (solar drying) lebih baik dari segi warna dan tidak berjamur dari pada kakao hasil pengeringan secara langsung sinar matahari (open sun drying).

\section{Saran}

Untuk meningkatkan upaya penghematan energi sekaligus pemanfaatan energi terbarukan serta optimasi proses pengeringan, maka perlu dilakukan penelitian lanjutan tentang pengeringan 
kakao dengan metoda solar thermal yang dapat beroperasi pada temperatur lebih tinggi $\left(55-65^{\circ} \mathrm{C}\right)$ dan tidak bersifat intermitten.

\section{Daftar Pustaka}

Anonim, 2009. Profil singkat komoditi kakao.http://regionalinvestment.com/ sipid/id/userfiles/komoditi/3/kakao_pr ofilsingkat.pdf. Tanggal akses 15 Februari 2009.

Anonim ${ }^{a}$. 2009. Dengan fermentasi untung petani kakao meningkat. http://www.sinartani.com/olahanpasar Idengan-fermentasi-untung-petanikakao-meningkat-1259555516.htm. Tanggal akses 14 Desember 2009.

Clement A. D., Assidjo N. E., Kouame P., Yao K.B. 2009. Mathematical modelling of sun drying kinetics of thin layer cocoa (theobroma cacao) beans. Journal of applied sciences research, 5 (9): 1110 $-1116$.

Dina S.F, Farel H. Napitupulu, Himsar Ambarita. 2013. Kajian berbagai metode pengeringan untuk peningkatan mutu kakao Indonesia. Jurnal riset industri, Badan pengkajian kebijakan iklim dan mutu industri kementrian perindustrian. Vol 7 no. 3 .

Doymaz, I. 2005. Sun drying of figs: an experimental study. Journal of food engineering 71, 403-407.
Fagunwa A.O., Koya O.A. and Faborode M.O. 2009. Development of an intermittent solar dryer for cocoa beans. Agricultural engineering international: the CIGR Journal. Manuscript number 1292, vol XI, July, 2009.

Hii C.L., Law C.L., Cloke M. 2009ª . Modelling using a new thin layer drying model and product quality of cocoa. Journal of food engineering, (90): 191 - 198.

Hii C.L., Law C.L., Cloke M., Suzannah S. $2009^{b}$. Thin layer drying kinetics of cocoa and dried product quality. Biosystem engineering (102): 153 161.

Hii C.L., Law C.L., Cloke M. 2009 ${ }^{\circ}$. Determination of effective diffusivity of cocoa beans using variable diffusivity model. Journal of applied sciences, 9 (17): $3116-3120$.

Jangam, S.V. and Mujumdar, A.S. 2010. Basic Concepts and Defenitions, in Drying of Foods, Vegetables, and Fruits, Published in Singapore, pp. 1-3.

Karathanos, V.T. 1999. Determination of water content of dried fruits by drying kinetics. Journal of Food Engineering, (39): 337-344.

Sharma, A., Chen C.R., Nguyen Vu Lan. 2009. Solar-energy drying systems: A review, Renewable and Sustainable Energy Reviews, (13): 1185-1210. 